\title{
(In)Terminable intervention in Bosnia and Herzegovina
}

Walter Laudes (2009) Der Hohe Repräsentant für Bosnien und Herzegowina. Der Vertreter der Internationalen Gemeinschaft - eine Bilanz des Amtes Egon Verlag: Würzburg

\section{What is at stake}

When compared to the interventions of the 'international community' in Afghanistan and Iraq, but also in Kosovo, the regional stabilisation, the peace implementation and state-building mission in Bosnia and Herzegovina (hereinafter 'Bosnia') is evidently showing some positive results and trends. So much so that the country has largely been off the radar screen in recent years, despite the deterioration of the political situation in the country since 2009. Of course, Bosnia is not Iraq or Afghanistan, for many reasons, but it also illustrates how complex and long-lasting have been the postwar transition, and the peace- and nation-building, processes.

Indeed, some 15 years after the General Framework Agreement for Peace (GFAP) brokered in Dayton, the country seems unable to move 'beyond Dayton' ${ }^{1}$ and to speedup both the country's own integration - thus, overcoming its split into two entities, strengthening the central state - and its European Union integration process. Worse, the international community seems to have no exit strategy and the Office of the High Representative (OHR) has, meanwhile, lost most of its credibility and authority. Subsequent to March 2006, the Peace Implementation Council (PIC) has continually been discussing how and when to close the OHR - with no result to date. This is nothing new; back in 2003, when the European Stability Initiative (ESI) sharply criticised the OHR's use of the 'Bonn powers', ${ }^{2}$ the related question was already on the table of 'Is there such a thing as a natural end to an intervention?'3

\section{Laudes' input}

Among the valuable books published in 2009 in the German-speaking area, Walter Laudes' contribution, reviewing the OHR mission, offers the opportunity to examine this question. The author was involved in the country in 1990-2000 - as SFOR Senior Liaison Officer to International Organisations - and in 2003-2004, first as OHR Head

1 See a first critical assessment in Christophe Solioz and Tobias K. Vogel (Eds.) (2004) Dayton and Beyond: Perspectives on the Future of Bosnia and Herzegovina Baden-Baden: Nomos.

2 See my contribution in Christophe Solioz (2003) 'Challenges of Controlled Democracy', Balkan Reconstruction Report Transitions Online 7 August. The 'Bonn powers' refers to the High Representative's extended authority, promulgated at the Bonn Peace Implementation Conference on 10 December 1997.

3 I deliberately mirror the Freudian question 'Is there such a thing as a natural end to an analysis?', Sigmund Freud (1937) Analysis Terminable and Interminable Standard Edition, Vol. 23, p. 219. 
of Central Office of the RRTF; and, later on, as personal assistant (in the field of military reform) to the Senior Deputy of the High Representative.

Laudes starts with a short but effective overview of the GFAP, insisting on the specificity and uniqueness of the OHR mandate (Chapters 3 and 4). He then highlights the importance of the agencies' co-ordination mechanisms, notably between the military and civil sectors, and the strategic role played herein by the OHR. The Board of Principals, established in 2002 by the then High Representative, Wolfgang Petritsch, decisively enhanced the much-needed co-ordination ${ }^{4}$ - this illustrated the capacity of the OHR to adapt its structures to the requirements in the field (we may ask if this is still the case today). Laudes notes that the PIC Steering Board (PIC SB) has played a decisive role in this situation. ${ }^{5}$ The High Representative's position is a complex one: he has to co-ordinate the Steering Board but he is also 'controlled' by the PIC ambassadors who regularly refer to their respective foreign affairs ministers. Thus, the High Representative has both to direct and convince as primus inter pares.

The author then goes to review (in Chapter 5) the most convincing cases of cooperation: with the UN Mission to Bosnia in the framework of the International Police Task Force (IPTF), which introduced the police reforms; the jointly established Reconstruction and Return Task Force (RRTF) (Chapter 13 discusses the details); and then with the OSCE, particularly in the field of military reform (Chapter 14 offers the finer points). Laudes also considers the gap between the civil and military sectors, screening OHR's relationship first with the NATO-led Implementation Force (IFOR) up to the end of 1996, and then with the Stabilisation Force (SFOR) up to 2004.

Co-operation proved to be almost impossible until 1999; at that time, SFOR finally accepted the need to support the work of the RRTF in protecting the returns process. The author recalls that, in March 1996, IFOR refused to intervene - at the request of the OHR - when some 70000 Serbs from Sarajevo, following pressure by the leaders of the Serbian Democratic Party (SDS), uprooted themselves and left in an exodus for Republika Srpska (RS) or for Serbia.

The gap was definitively overcome at the end of 2004, when NATO handed over its duties to the EU-led European Force (EUFOR). As a matter of fact, one of EUFOR's core tasks is supporting the OHR in its mission.

Laudes then introduces (in Chapter 6.1) the various High Representatives, ${ }^{6}$ starting with Carl Bildt (1995-1997), who established the OHR in late 1995, up to the period

4 Under the Chair of the High Representative, the Board of Principals, meeting once a week in Sarajevo, serves as the main co-ordinating body of international community activity in the country. Its permanent members are the OHR, EUFOR, NATO HQ Sarajevo, OSCE, UNHCR, EUPM and the European Commission. The international financial institutions, such as the World Bank, the IMF and the UNDP, are also regular participants. At stake are the co-ordination and, above all, the coherence of the international action.

5 The PIC comprise 55 countries and agencies, while the Steering Board's members are Canada, France, Germany, Italy, Japan, Russia, United Kingdom, United States, the Presidency of the European Union, the European Commission and the Organisation of the Islamic Conference (OIC), which is represented by Turkey.

6 After early 2002, the High Representative has also been known as the European Union Special Representative (EUSR). 
of office of Miroslav Lajčák (2007-2009). The following section (Chapter 6.2) presents the development of the OHR's structure and budget, highlighting the years 1999-2002: a period - eventually the most successful one - in which both the budget $(€ 30.5 \mathrm{~m}$ in 1999) and staff (700 people in 2002) were particularly consistent, compared to the $€ 11.3 \mathrm{~m}$ and 223 positions in 2009 . The decrease is explained by diminishing resources and also by the successful strategy of the handing-over to the local authorities of OHR competencies. Accordingly, the regional and field offices, as well as units and/or departments, were closed down in Sarajevo - following the OHR benchmarks as established by its Mission Implementation Plan (MIP). ${ }^{7}$

\section{The first four High Representatives}

This more informative section provides accurate information and a valuable description of OHR's main structural trends between 1995 and 2009, while the core part of the book (Chapters 7 to 12) gives more space to the political work of each High Representative. The author insists on the positive repercussions of the almost simultaneous changes in the first half of 1997 in the UK and US political landscapes; the election of Tony Blair and Bill Clinton contributed to a strengthening of the position of the first High Representative, Carl Bildt (Chapter 7). Additionally, the PIC Conference in Sintra (May 1997) accepted the introduction of the 'conditionality policy' which provided the OHR with significant means to influence local stakeholders. The author considers this as a main achievement of Bildt's period of office (Chapter 7), on which the next High Representative, Carlos Westendorp, could build (Chapter 8).

The OHR gained in efficacy also because, as mentioned above, SFOR started actively to support the OHR. Not by chance did significant political changes happen during the same period in the RS: Radovan Karadžić lost the entity election and Mirolad Dodik, at that point a moderate politician - a false assumption - became the new RS Prime Minister. In order to be able fully to implement his policy, Westendorp requested, and obtained, at the Bonn PIC conference in December 1997 the so-called 'Bonn Powers', which conferred the High Representative with real authority - namely to sack officials who were obstructing the peace implementation process and to pass laws (Section 16.4 offers a short, but good, overview of the various viewpoints on this issue). Key decisions were then quickly imposed by Westendorp: a new law on citizenship; the introduction of a single currency (the Konvertibilna Marka); a flag; a common vehicle registration plate; and a single passport. This enhanced (cross-entity) freedom of movement and contributed to the strengthening of the Bosnian state (an issue further discussed in Chapter 15).

Thus, the OHR moved a step forward: beyond peace-implementation and reconstruction, it started to play a proactive role in the complex post-war nation and state-

7 The purpose of the MIP - introduced in 2003 - was to identify the core tasks on which the OHR needed to concentrate 'in order to accomplish its mission'. Paddy Ashdown, then the High Representative, stated that it was seen as a 'tool for gauging our performance, the deployment of our resources and our accountability to our paymasters and to the people of Bosnia and Herzegovina' (OHR, Sarajevo, January 2003; quoted from http://www.ohr.int). 
building processes. Westendorp's effective work paved the way for other key changes brought in by his successor, Wolfgang Petritsch (Chapter 9).

Petritsch first introduced the idea of working according to a two-year programme. ${ }^{8}$ The key priorities of his three-pillar approach were: first, economic development; second, the return of displaced people and refugees; and, third, the reinforcement of the institutions (thus, state-building). Petritsch also pioneered a strategic concept: ownership. ${ }^{9}$ Using the 'Bonn Powers' whenever necessary, the High Representative's strategy consisted essentially of enhancing the role of local stakeholders.

In reviewing the main achievements within Petritsch's key priorities, the author explains less successfully the relevance of his philosophy and pragmatic approach. Indeed, this approach also introduced key constitutional changes at entity-level through the Sarajevo-Mracovica Agreement (mentioned by the author en passant in another chapter, p. 176). This accord - negotiated in March 2002 with almost all Bosnian political leaders - grants the same status to all constituent people and citizens across the whole territory of the country; it also creates mechanisms assuring the protection of the interests of each community as well as their representation in the decision-making organs. ${ }^{10}$ Unfortunately, the author also forgets another key issue and result. Petritsch had a vision for the country: an 'entry strategy' instead of an 'exit strategy' - Bosnia's European integration. A first step was achieved on 24 April 2002, when Bosnia became a member of the Council of Europe.

One month later, his mission complete, Petritsch handed over his position to Paddy Ashdown (Chapter 10), who successfully pursued the reform process in the fields of justice, the economy, the military and the EU integration process. Systematically, new state-level agencies or ministries were created and, whenever possible, OHR competencies were handed over to local authorities. Thus, the entity-level became less relevant whereas the state-level was significantly strengthened (with ten ministries instead of six). Laudes highlights that Ashdown could not use the 'Bonn Powers' notably in the military and police reforms; each time, it was up to the Bosnian parliament to pass the reforms. Ashdown used the EU conditionalities in order to convince the Bosnian leaders: indeed, many reforms corresponded to the requirements of the European Commission's feasibility study.

Laudes regards Ashdown's action as mostly successful. One of his major achievements was that, at the end of 2005, Stabilisation and Association Agreement (SAA) negotiations were officially opened in Sarajevo. Only the reform of the police was opposed in the RS by an increasingly reluctant Dodik.

\section{The three last High Representatives}

It could have been that 2005 was the right time to close the OHR. Contrary to what the author states, Ashdown did not work specifically on the OHR's closure (for exam-

8 This strategy was followed by Paddy Ashdown with the introduction of the MIP.

9 See Christophe Solioz and Svebor Dizdarevic (Eds.) (2003) Ownership Process in Bosnia and Herzegovina Baden-Baden: Nomos. The book was first published in Sarajevo in 2001.

10 See Christophe Solioz (2005) Turning Points in Post-War Bosnia. Ownership Process and European Integration Baden-Baden: Nomos, Second Edition 2007, pp. 96-97. 
ple, he omitted to set up a specific task force), assuming his successor, Christian Schwarz-Schilling (Chapter 11), would complete his work and close the OHR - which turned out to be wrong. Certainly, the election results in October 2006 changed the political situation in the country: Haris Silajdžić, elected member of the presidency, and Dodik, again RS Prime Minister, systematically opposed each other, de facto blocking the reform process achieved during the 1995-2005 years.

Dodik proceeded to go even further, wanting to bring back to the entity-level the power which had been conceded to the state in recent years. Worse, his rebranded hatespeech clearly threatened the constitutional order of the country. Later, in May 2009, he acted accordingly: the 14 May declaration, adopted by the National Assembly of RS, called for the return of entity jurisdiction over the competencies which had been transferred to the level of the state by the order of the OHR. The then High Representative, Valentin Inkzo, adopted a tough stance, over-ruling the RS parliamentary declaration that challenged its authority.

For his part, Silajdžić wanted to abolish the RS; this was also contrary to the GFAP.

The closure of the OHR was repeatedly postponed and significant divergences appeared publicly inside the international community, mainly between the American administration and Schwarz-Schilling. This would eventually weaken the OHR and its credibility. In any case, the OHR appeared unable to rein in Dodik's and Silajdžić's respective rhetoric. It is not clear if Schwarz-Schilling decided himself to resign (on 23 March 2007) or if he was sacked; in any case, his tenure was counter-productive and disappointing - the author opts here for the more moderate evaluation. In 2005, the OHR was close to success, to be able to end its mission leaving Bosnia as a strengthened state; in 2007, however, the OHR was having to prolong its presence while the sovereignty of the state was endangered.

Laudes reviews the key aspects of this period and concludes that the reforms had not truly been implemented; that the country was not yet ready to exist without the OHR. The author could have re-introduced here his analysis of the level of co-operation between the OHR and its partners. After Ashdown's departure, it seems that each wanted to go its own way - not only the international community but the local representatives too. In this situation, the succeeding High Representative, Miroslav Lajčák (Chapter 12), had to face a complex and difficult situation.

The first relevant measures proposed by Lajčák in October 2007 were directed towards improving the work of the Council of Ministers and of both houses of the parliamentary assembly - the House of Representatives and the House of the People. The politicians of the RS reacted promptly, defying and overturning the decisions; this was the most significant crisis since 1995. That the High Representative accepted that there was a need to compromise - because, as the author correctly mentions, Javier Solana opposed the use of the 'Bonn Powers' - was interpreted as a loss of credibility and authority. Nevertheless, Lajč́k - again compromising, or acting pragmatically was able to achieve the reform of the police, a move that allowed the country and the EU to sign the SAA on 16 June 2008.

Despite this major achievement, the other conditions requested by the PIC were not met by the local authorities, and the closure of the OHR was again postponed. 
Laudes mentions here PIC's strategic shift: from a time-driven to an event-driven approach: a set of key objectives ${ }^{11}$ needed to be achieved by the Bosnian authorities prior to the 'transition' of the remaining OHR competencies to the Bosnian authorities. Unfortunately, the author omits any reference to the 'Butmir talks' (2008) and the 'Prud process' (late 2008-early 2009). The latter, a genuine Bosnian negotiation process, involved politicians from the three leading parties (Sulejman Tihic for the SDA; Dragan Čović from the HDZ BiH; and Mirolad Dodik from the SNSD); while the Prud Agreement pertains to state property, the census, constitutional changes, the reconstruction of the Council of Ministers and the resolution of the legal status of the Brčko District - the latter consisting of an amendment to the GFAP, a significant break through.

Thus, the Prud Agreement partly solved the 5+2 requirements. The political leaders even went so far as to open discussions on a new decentralised plan for the country with three levels of government. This initiative, even if short-lived because of the start of the pre-electoral campaign, illustrates the local capacities... when the political will is present.

\section{How (not) to end}

In his conclusion (Chapters 16 and 18), Laudes presents his perspective: the OHR may walk out of the country only once the situation permits such a withdrawal, and this is not yet the case - the 'Bonn Powers' are still necessary. Nevertheless, against the background of the OHR's lack of credibility and the loss of power and influence, the PIC may, sooner or later, decide to soften the $5+2$ requirements and accept compromise - as it did in the case of the reform of the police.

Considering the need to introduce constitutional changes and to speed-up the EU integration process, a strengthened EUSR should take the follow-on measures (the EUSR being, at the same time, the Head of the EU Commission); the EUFOR mandate needs to be extended beyond the closure of the OHR; and the EUPM must overview the implementation of the police reforms. Following Lajčák's arguments, the author also foresees a tailored EU integration process that would take into account the country's complex post-conflict transition process.

Laudes further raises an important issue: the international community - meaning the PIC - and the EU member states in particular are divided among themselves when it comes to the question of when and how to close the OHR, and how to shape the postOHR period. The OHR, broadly the 'international community', was successful when-

11 This refers to the so-called PIC 5+2 requirements. The five objectives are: the acceptable and sustainable resolution of the issue of the apportionment of property between the state and other levels of government; the acceptable and sustainable resolution of defence property; the completion of the Brčko final award; fiscal sustainability (promoted through an agreement on a permanent ITA co-efficient methodology and the establishment of a national fiscal council); and the entrenchment of the rule of law (demonstrated through the adoption of a national war crimes strategy, the passage of the Law on Aliens and Asylum, and the adoption of the National Justice Sector Reform Strategy). The two conditions are: the signing of the $\mathrm{SAA}$; and a positive assessment of the situation in Bosnia by the PIC SB, based on full compliance with the Dayton Peace Agreement. Source: http://www.ohr.int/pic/default.asp? content_id=41352. 
ever it implemented a shared and coherent strategy. Now, above all, the EU member states must align their Bosnian policies.

To return to our opening question, we may say there is no natural end to an intervention: a new agenda and a convincing strategy are needed. This is precisely what has been missing in Bosnia since 2006.

Laudes himself is well aware of some of the limits of his book: written as the OHR has not yet been closed, some decisive questions are obviously still open and thus cannot be properly examined; the focus on RRTF, the military reform and the co-ordination of the civilian organisations and agencies is welcomed and well done, but a more comprehensive approach should, of course, cover all the OHR's activity sectors. The focused activities are well presented, but the OHR's key role in institution building and its influence in the economic sector should have been given more space.

All in all, the book is mostly descriptive and informative; thus, it is perfect as a global introduction. However, a much more detailed presentation and in-depth political analysis - focusing on all the negotiatory initiatives, and there were many - are needed in order to encompass the investigated field.

Finally, the author's secondary literature covers only a small segment of the considerable studies produced on Bosnia: the absence of the discussion of some standard works weakens the volume. Laudes refers to some 'local-based', thus Bosnian, comments but this needs to be made more central to the case and also methodologically reflected.

Ultimately, Laude's work is a welcome reflection which opens the way to further in-depth analyses. These should also be based on the archives of the OHR, notably nonpapers that would permit an investigation of the OHR's decision-making processes and strategic choices.

Christophe Solioz is Secretary-General of the Centre for European Integration Strategies (CEIS) in Geneva. He is the co-director with Wolfgang Petritsch of the series Southeast European Integration Perspectives at the Nomos publishing house. He recently published Retour aux Balkans. Essais d'engagement 1992-2010 Paris: L'Harmattan, 2010. 